One new line of great significance is the study of inter-molecular interactions through the displacements of vibration bands. This may lead to valuable information about adsorption processes, adhesion, and the formation of intermolecular complexes in reacting systems.
Many of these more elaborate contributions to research problems are of real interest; but it is important not to lose sight of the more mundane and urgent needs of analytical process control mentioned above. There are hopeful signs that the necessary instruments may soon become available.

\title{
OBITUARIES
}

Prof. Megh Nad Saha, F.R.S.

The death on February 16 from sudden heart failure, at the age of sixty-two, of Prof. M. N. Saha has robbed India of one more of her leading men of science. $\mathrm{He}$ was well known for his distinguished researches, for his activity in scientific administration and for his other public activities. After an early education in India he came to England for postgraduate studies under Prof. Alfred Fowler at the Imperial College of Science and Technology, London. It was there that he developed his work on thermal ionization, which led up to 'Saha's equation', by which he will be remembered. By taking account of the important effect of pressure, as well as of temperature, in a gaseous mixture of neutral atoms, ions and electrons, he explained the increase in ionization as one moves outwards from the photosphere to the chromosphere of the Sun. His work led to important developments by R. H. Fowler and E. A. Milne in the study of the pressures and temperatures of stellar atmospheres. It has carned a permanent place in the history of astrophysics.

On going back to India, Saha returned to physics, and as professor of physics successively at the Universities of Allahabad and Calcutta he founded research schools on ionospheric problems and nuclear physics. He published many papers on a wide range of subjects, including the propagation of electromagnetic waves in the ionosphere, the escape of radio waves from the Sun, nuclear physics and spectroscopy. His position in the world of Indian science may be gathered from the many leading positions that he held from time to time. He was president of the Indian Science Congress, of the United Provinces Academy of Science (later the National Academy of Sciences), and of the Indian Association for the Cultivation of Science and the National Institute of Sciences. He was largely instrumental in founding the Institute of Nuclear Physics, Calcutta; as its director he was active both in training students and in supervising research work.

$\mathrm{He}$ was a member of the Board (or later Council) of Scientific and Industrial Research, which led to growing interest in the social relations of science, a subject on which he wrote a number of papers. As he grew older and became an established figure in his own country, he turned more and more to questions of education, industrialization, national planning and such details as river valley projects. [His last paper of this kind appears on p. 923 of this issue of Nature.] In 1951 he was elected to the Indian Parliament by a large majority as an independent member, having refused to stand as a party candidate. $\mathrm{He}$ loved fighting for causes which he felt to be right, even though by so doing he earned unpopularity in Government circles. But he retained a keen, active interest in science, and only last year was one of the Indian members attending the General Assembly of the International Astronomical Union in Dublin.
His sixtieth birthday was celebrated by a volume on his life, work and philosophy arranged by a committee of the Indian Association for the Cultivation of Science (see Nature, 174, 528; 1954). It is sad that he should have survived its publication for so short a time. F. J. M. Stratton

\section{Mr. T. Harold Reade}

Thomas Harold Reade, the third son of the late Thomas Reade, manufacturing chemist, of Wolverhampton, was born in 1889 . He was educated at $\mathrm{St}$. Paul's School, London, where he was a contemporary of Lord Montgomery, and at the University of Birmingham, where he graduated in science. During the First World War, Reade served in France and in Palestine, first with the 6th South Staffordshire Regiment and later with the Machine Gun Corps. On demobilization he went to Emmanuel College, Cambridge, where, under Dr. Hamilton McCombie, he carried out research on the preparation and properties of phenyltrimethylammonium perhaloids, perfecting methods for the determination of the constitution of these compounds. In 1921, Reade graduated and was appointed to the staff of the University of Aberdeen, where he became responsible for the teaching of organic chemistry, a duty which he performed with thoroughness and distinction until his retirement in 1945. A man of strong personality, a trifle impetuous, he was an inspiring teacher and a pleasant colleague.

Throughout his period on the University staff, Reade maintained an active research programme. Following on his work at Cambridge, he studied the addition compounds of halogens and quaternary ammonium salts, showing experimentally that the iodine in these perhalides is reducible but not oxidizable to molecular iodine and therefore is in a higher state of oxidation. Later, in collaboration with his research students, he investigated, among other problems, the simultaneous nitration of the nucleus and nitrosation of the nitrogen atom in a considerable number of dialkyl anilines by means of sodium nitrite in hydrochloric and sulphuric acids, finding a method of controlling the type of reaction that predominated. The numerous contributions which he made in these various spheres are recorded in the Journal of the Chemical Society.

In his retirement Reade devoted his leisure to golf and music; he was an accomplished performer on both the golf course, where on many occasions he represented the staff of the University of Aberdeen in inter-university competitions, and on the piano. His sudden death, on March 24, came as a great shock to his many friends; taken ill while playing his usual game of golf at his club, the Royal Aberdeen, he died a few hours later in hospital. He was unmarried.
R. B. StRathDEF 